\title{
ENERGY USE EFFICIENCY AND GREEN HOUSE GAS EMISSIONS FROM INTEGRATED CROP-LIVESTOCK SYSTEMS IN SEMI-ARID ECOSYSTEM OF DECCAN PLATEAU IN SOUTHERN INDIA
}

\author{
Md. Latheef Pasha ${ }^{1}$, G Kiran Reddy ${ }^{2} *$, S Sridevi ${ }^{3}$, M Govardhan $^{4}$, Md. Ali Baba ${ }^{5}$, B. Rani ${ }^{6}$
}

\author{
${ }^{1}$ Senior Scientist (Agronomy), AICRP-IFS, Hyderabad - 500030 \\ ${ }^{2}$ Scientist (Soil Science), AICRP-IFS, Hyderabad - 500030 \\ ${ }^{3}$ Principal, Agricultural Polytechnic, Tornala \\ ${ }^{4}$ Principle Scientist \& Head, AICRP-IFS, Hyderabad - 500030 \\ ${ }^{5}$ Scientist (Agricultural Economics), AICERP-IFS, Hyderabad - 500030 \\ ${ }^{6}$ SRF, AICRP-IFS, Hyderabad - 500030
}

Received - January 19, 2020; Revision -March 20, 2020; Accepted - March 28, 2020

Available Online - April 25, 2020

DOI: http://dx.doi.org/10.18006/2020.8(2).98.110

\section{KEYWORDS \\ Integrated crop-livestock \\ system \\ Greenhouse gas (GHG) \\ emission \\ Energy use \\ Sustainability \\ Input energy \\ Positive energy balance}

\begin{abstract}
Integrated crop-livestock system is the default in vogue farming system followed in semi arid Deccan plateau in Southern India. Energy flow and environmental impact plays an anchor role for the sustainability of any farming system. The objective of the present study is to know the energy use and greenhouse gas (GHG) emission in the integrated crop-livestock systems in study area. Primarily data was collected from 36 farmers by bench mark survey questionnaire. The study area includes 54.53 ha of cultivated land, 177 dairy cattle, 466 sheep and 129 poultry birds. Total input energy required for crop production and livestock management was 1598441.0 and 6168311.9 MJ respectively, output energy generated was 9063909.8 and 408331.0 MJ respectively. Even livestock enterprise have shown negative energy balance (-5759980.9 MJ), overall system has shown positive energy balance of 1705487.9 MJ as crop enterprise offset the ill energy efficiency of livestock enterprise. Rice emits highest amount of $\mathrm{CO}_{2 \mathrm{eq}}\left(3099.4 \mathrm{~kg} \mathrm{CO}_{2} \mathrm{eq} \mathrm{ha}{ }^{-1}\right)$ among crops in study, around $50 \%$ is contributed by submergence (continuous flooding). Total GHG emission from the study area was $532215.3 \mathrm{~kg} \mathrm{CO}_{2}$ eq. Out of which, $26.1 \%$ and $73.9 \%$ of the emissions were emitted by crop (138637.3 $\mathrm{kg} \mathrm{CO}_{2}$ eq) and livestock enterprise (393578.0 $\mathrm{kg} \mathrm{CO}_{2} \mathrm{eq}$ ). Both the cases crop enterprise has greater advantage over the livestock enterprise. The key policy implication from the current study was integrated crop-livestock system will sustain in long run, as less energy use and higher GHG emissions of livestock enterprise will be nullified by the crop enterprise.
\end{abstract}

* Corresponding author

E-mail: gkiranreddy43@gmail.com (G Kiran Reddy)

Peer review under responsibility of Journal of Experimental Biology and Agricultural Sciences.

Production and Hosting by Horizon Publisher India [HPI] (http://www.horizonpublisherindia.in/).

All rights reserved.
All the articles published by Journal of Experimental Biology and Agricultural Sciences are licensed under a Creative Commons Attribution-NonCommercial 4.0 International License Based on a work at www.jebas.org.

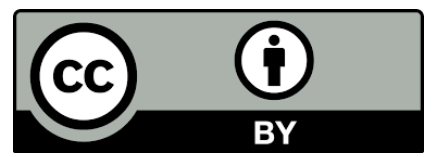




\section{Introduction}

Agriculture is the base for livelihood of $66 \%$ of the Indian population and it contributes $20 \%$ of national gross domestic products. It is the source for national food security (ICAR, 2015). In 1970's, with advent of green revolution in India, one side it increased the food grain production. It directly or indirectly increased the livestock population, as the energy availability increased. Other side fertilizer and other external inputs usage increased manifold resulted in deterioration of soil health, thereby paradism shift in energy use and GHG's (green house emissions) emissions over a period. Agriculture requires large energy and potent source of GHG as stated by Hoffman et al. (2018).

Nearly $85 \%$ of the Indian farmers fall under the category of small and marginal farmers with acreage less than 1 ha. Initial investment capacity of the Indian farmers is very low. Investment should not impair the crop productivity. So, the cost of cultivation should be kept low. In addition to economic analysis, energy analysis which indicates the inputs to be minimized and energy use has to be increased. Farming uses the energy in different capacities e.g. machinery, human power, seed, diesel, animal power, irrigation etc. An agricultural production system is to be efficient, if it produces more output (output energy) with minimum input energy (especially non reneweable inputs). This makes the agricultural production system viable in environmental and economic terms (Sefeedpari et al., 2012). It is very useful to analyse crops in terms of energy. This should be done without impairing the yield of the crops.

Livestock and land utilization are the critical factors for the GHG emissions. Farming contributes around $10-12 \%$ of the GHG globally (IPCC, 2007). The share in India context is a bit higher side at $18 \%$ (INCCA, 2010). Farming is in third line after energy and industry sector in GHG emissions in India. In Indian agriculture system, farmers cultivate versatile crops and maintain livestock for the livelihood and nutrition security to family. Mixed crop-livestock farming is age old practice, which provides food for more than half of the world's population (Ghahramani \& Bowran, 2018). So, such farming systems environmental impact assessment is also an important factor. Most part of GHG from farming in India is contributed by the livestock (Steinfeld et al., 2006). From global food security point of view livestock plays a very critical role, as it is meeting the $17 \%$ of global energy and $33 \%$ of protein requirement (Rosegrant et al., 2002). Animal protein demand is increasing day by day globally in general and semi arid deccan plateau in Southern India in particular. Increased per capita income is also playing a pivotal role for the increasing consumption and demand for animal products in this part of world. In addition, increase in animal population also has other benefits like, provides organic matter, which is wealth for poor farmers etc.
In regarding the Deccan plateau in Southern India, livestock - crop integration system is a principle farming pattern adapted by bulk of the cultivators. India is also one of the leading producers of rice and milk. Wide variety of crops like rice, maize, groundnut, cotton, sorghum, vegetables etc. are grown. More or less all farm families will maintain livestock (either dairy, sheep, poultry etc.).

Highly scarce information is available regarding the impact of different farming systems on energy use and GHG emissions in the Deccan plateau of Southern India. An attempt was made to evaluate the energy sequestered in integrated crop-livestock farming system, the energy sequestration of different crops, livestocks and GHG emission from livestock and crop management in Southern Deccan plateau region of India.

\section{Materials and Methods}

\subsection{Description of study area}

The survey was conducted under All India Coordinated Research Project on Integrated Farming System, as part of On Farm Research in Medak district of Telangana State in Southern India. The area of surveyed includes two blocks of Medak district i.e. Yeldurthy and Toopran covering three villages in each block. Three representative villages from each block i.e. six villages for each district were selected randomly. From each village six farm households were chosen at a random keeping in mind that at least four households should represent each farming system. Yeldurthy and Toopran blocks were the typical blocks of Medak districts, which are located $100 \mathrm{kms}$ east of capital city Hyderabad (Telangana State). Study area is situated in the central part of Telangana State. Its coordinates are $17^{\circ} 27^{\prime} 0^{\prime \prime}-18^{\circ} 19^{\prime} \mathrm{N}$ latitude, $17^{\circ} 27^{\prime} 0 "$ - $18^{\circ} 19^{\prime}$ E longitude $442 \mathrm{~m}$. Study area comes under Southern plateau and hill zone agroclimatic zone of India. The mean annual rainfall was $861 \mathrm{~mm}$, the mean temperature of the study area was $26.8^{\circ} \mathrm{C}$. Climatic condition of the region is tropical. Before commencement of the study, the strong research methodology was developed to investigate the targeted farmers via. statistical and scientific methods through prepared questionnaire. Overall 36 farmers were surveyed in the year 201718 for a period of one year from June, 2017 to May, 2018. Farmers in the study area grow crops like rice, maize, fodder sorghum, tomato, okra, cotton groundnut there acreages are 37.74, 14.04, $0.25,0.9,0.3,1.0,0.2$ ha respectively. With regard to livestock, total of 177 dairy cattle, 466 sheep and 129 poultry were maintained by 36 farm families in total. All the farmers were following integrated livestock and crop farming system in different proportions. Geographic and meteorological features of the surveyed villages were similar to other villages, where the integrated livestock-crop farming systems were practiced in this part of world. 


\subsection{Collection of data}

The data regards to the complete production of crops and live stocks were assessed from the targeted farmers by detail interview with individual farmer with the help of bench mark survey questionnaire in the study area. General information of farmer such as holding size, farm land details, farm machinery and equipment, crop wise input used like seed, fertilizers, human labour, bullock labour, chemical, oils used. Production of various farm out puts (rice, maize, tomato and fodder etc) and disposal of produce livestock details like number of animals, fodder, concentrates, mineral mixture, livestock products were reported in detail to calculate the energy balance and GHG emissions.

\subsection{Calculations of energy balance and GHG emissions}

Various inputs were used for the production of crops and maintenance of livestock, outputs that were generated by using the inputs and their energy equivalents are presented in table 1 (ubiquitous environmental sources of energy i.e. radiation, wind etc. was not taken into account). Energy equivalents present in the table 1 were used to calculate the input and output energy values i.e., the input energy which was utilized to produce the output energy. Input energy classified into direct (labour, fuel and electricity) and indirect energy (fertilizers, chemicals, machinery, irrigation, manures and seed), renewable (labour, organic manures and seed) and non renewable energy (fuel, fertilizers, chemicals, machinery and water). Output energy like the energy embodied in the crops, livestock products and byproducts were considered.

Different values generated from the input and output energy were used to calculate the energy use efficiency, energy productivity, specific energy, net energy, land use efficiency, non renewable energy ratio, direct energy, indirect energy, renewable energy and non renewable energy (standard formulas are given in table 2). Land use efficiency is the amount of energy generated in a given unit of land. The ratio between total output and input energy is the energy use efficiency. Net energy is the difference between the total output energy generated minus total input energy supplied to produce the crop. Energy productivity is the quantity of crop produced by the supply of given amount of energy. Non renewable energy ratio is the same as energy use efficiency except it considers only non renewable energy used for the crop production.

GHG emissions were in principle calculated with default emission factors, as cited by many authors. In present study different factors that contribute to the GHG emissions were machinery, diesel, N, P, K chemical fertilizers, FYM, electricity, chemicals, rice under submergence, production of milk, FYM, mutton, eggs and poultry. Default factors per unit for the above said factors were used to calculate the GHG emissions (Table 3).
The present study accounts only for farm management (within the farm gate) do not account for outside the farm gate. Calculation was done up to the farm gate only.

\section{Results and Discussion}

\subsection{Energy use analysis}

The data collected from the surveyed area covering 36 farmers with total acreage of 54.43 ha under crops (occupied by rice, maize, fodder sorghum, tomato, okra, cotton and groundnut), 177 dairy cattle, 466 sheep and 129 poultry birds; these data helps in characterizing the energy use by 36 farmers of the study area in crops and livestock. Input quantities used for production of crops are presented in table 4, input and output energies for crop production are presented in table 5. In production of crops, input energy per unit area crop production varied considerably among crops. The input energies for the production of rice, maize, fodder sorghum, tomato, okra, cotton, groundnut were 1171215.0, 347730.5, 6096.8, 24959.7, 9561.7, 32629.3, 7247.5 MJ respectively. Total input energy for the crop production in the study area was $1598441.0 \mathrm{MJ}$. Input energies required to calculate for individual crops per ha to produce the output were $31007.2,24767.1,24387.3$, 27733.0, 31872.3, 32629.3, 36237.7 MJ for rice, maize, fodder sorghum, tomato, okra, cotton, groundnut respectively. Highest input energy required for the production of groundnut while the least one was observed in the fodder sorghum per ha area.

The output energy i.e. economic and byproducts energy varies with crops, presented in table 5 (in lower panal). The variation in yield depends on the genetic potential of crop and management practices. The output energy calculated for both economic and byproducts, the values for rice, maize, fodder sorghum, tomato, okra, cotton, groundnut were 6122882.0, 2702090.0, 59850.0, 58634.8, 23458.0, 75725.0, 21270.0 MJ respectively. Mean values of the output energy in $\mathrm{MJ} \mathrm{ha}^{-1}$ (table 5) were calculated as rice (162288.5), maize (192456.6), fodder sorghum (239400), Tomato (65149.8), okra (78193.3), cotton (75725.0) and groundnut (106350). Sartori et al. (2005) observed in the maize conservation farming, it requires input energy of $46900 \mathrm{MJ} \mathrm{ha}^{-1}$ and it generated 161980.0 $\mathrm{MJ} \mathrm{ha}^{-1}$ output energy. The overall output energy for the study area for crop enterprise was 9063909.8 MJ. Output energies produced by the crops were higher than the energy consumed for production (Table 5). The crop enterprise has produced a positive energy of $7465468.8 \mathrm{MJ}$ compared to consumed energy in the study area. Similarly, Tsatsarellis (1991) calculated the energy use in cotton and reported that cotton crop in total sequestrated energy of $82600.0 \mathrm{MJ} \mathrm{ha}^{-1}$. 
Table 1 Energy coefficients of inputs and outputs in integrated crop-livestock production

\begin{tabular}{|c|c|c|c|}
\hline \multicolumn{4}{|c|}{ Input } \\
\hline Item & Unit & Energy equivalent & Referance \\
\hline Human labour & $\mathrm{h}$ & 1.96 & Mobtaker et al., 2012 \\
\hline Bullock labour & $\mathrm{h}$ & 10.10 & Chandrakar et al., 2013 \\
\hline Diesel & $\mathrm{L}$ & 56.31 & Barber, 2004 \\
\hline Machinery & $\mathrm{h}$ & 62.70 & Rafiee et al., 2010 \\
\hline \multicolumn{4}{|l|}{ Seeds } \\
\hline a. Rice & $\mathrm{kg}$ & 14.70 & Mohammadi et al. 2014 \\
\hline b. Maize & $\mathrm{kg}$ & 14.70 & Mohammadi et al. 2014 \\
\hline c. $\quad$ Fodder sorghum & $\mathrm{kg}$ & 14.70 & Mohammadi et al. 2014 \\
\hline d. Tomato & $\mathrm{kg}$ & 0.96 & Gopalan et al., 2012 \\
\hline e. Okra & $\mathrm{kg}$ & 1.46 & Gopalan et al., 2012 \\
\hline f. Cotton & $\mathrm{kg}$ & 18.00 & Larson \& Fangmeir, 1978 \\
\hline g. Groundnut & $\mathrm{kg}$ & 23.73 & Gopalan et al., 2012 \\
\hline $\mathrm{N}$ & $\mathrm{kg}$ & 60.60 & Akcaoz et al. 2009 \\
\hline$P$ & $\mathrm{~kg}$ & 11.10 & Akcaoz et al. 2009 \\
\hline K & $\mathrm{kg}$ & 6.70 & Ozkan et al. 2004 \\
\hline FYM & $\mathrm{kg}$ & 0.30 & Devasenapathy et al., 2009 \\
\hline Electricity & $\mathrm{kWh}$ & 12.00 & Tsatsarellis, 1991 \\
\hline Herbicide & $\mathrm{kg}$ & 102.00 & Chaudhary et al., 2009 \\
\hline Pesticide & $\mathrm{kg}$ & 120.00 & Rahman \& Barmon, 2012 \\
\hline Insecticide & $\mathrm{kg}$ & 58.00 & Tabar et al., 2010 \\
\hline Dry fodder & $\mathrm{kg}$ & 12.50 & Mohammadi et al. 2014 \\
\hline Concentrates & $\mathrm{kg}$ & 11.71 & Petal, 2012 \\
\hline Green fodder & $\mathrm{kg}$ & 8.37 & Petal, 2012 \\
\hline \multicolumn{4}{|l|}{ Output } \\
\hline Rice & $\mathrm{kg}$ & 14.70 & Mohammadi et al. 2014 \\
\hline Rice straw & $\mathrm{kg}$ & 12.50 & Mohammadi et al. 2014 \\
\hline Maize & $\mathrm{kg}$ & 14.70 & Mohammadi et al. 2014 \\
\hline Maize stover & $\mathrm{kg}$ & 12.50 & Mohammadi et al. 2014 \\
\hline Fodder Sorghum & $\mathrm{kg}$ & 13.30 & Krishnamoorthy et al.1995 \\
\hline Tomato & $\mathrm{kg}$ & 0.96 & Gopalan et al., 2012 \\
\hline Tomato stover & $\mathrm{kg}$ & 13.00 & Mondal, 2010 \\
\hline Okra & $\mathrm{kg}$ & 1.46 & Gopalan et al., 2012 \\
\hline Okra stover & $\mathrm{kg}$ & 13.00 & Mondal, 2010 \\
\hline Cotton & $\mathrm{kg}$ & 15.50 & Larson \& Fangmeir, 1978 \\
\hline Cotton stalk & $\mathrm{kg}$ & 18.2 & Ozturk \& Bascetincelik, 2006 \\
\hline Groundnut & $\mathrm{kg}$ & 23.73 & Gopalan et al., 2012 \\
\hline Groundnut stover & $\mathrm{kg}$ & 17.58 & Koopmans \& Koppejan, 1997 \\
\hline Milk & $\mathrm{L}$ & 4.9 & Gopalan et al., 2012 \\
\hline FYM & $\mathrm{kg}$ & 0.3 & Devasenapathy et al., 2009 \\
\hline Mutton & $\mathrm{kg}$ & 4.94 & Gopalan et al., 2012 \\
\hline Eggs & $\mathrm{kg}$ & 7.24 & Gopalan et al., 2012 \\
\hline Poultry & $\mathrm{kg}$ & 21.75 & Cao \& Adeola, 2015 \\
\hline
\end{tabular}

Journal of Experimental Biology and Agricultural Sciences

http://www.jebas.org 
Table 2 Standard formulas used for calculation of different indices of energy use

Parameter Formula

Energy use efficiency

Energy productivity

Specific energy

Net energy gain

Land use efficiency

Non renewable energy

ratio

Direct energy

Indirect energy

Renewable energy

Non renewable energy
Output energy $\left(\mathrm{MJ} \mathrm{ha}^{-1}\right) /$ Input energy $\left(\mathrm{MJ} \mathrm{ha}^{-1}\right)$

Crop yields $\left(\mathrm{kg} \mathrm{ha}^{-1}\right) /$ Input energy $\left(\mathrm{MJ} \mathrm{ha}^{-1}\right)$

Input energy $\left(\mathrm{MJ} \mathrm{ha}^{-1}\right) /$ Output $\left(\mathrm{t} \mathrm{ha}^{-1}\right)$

Output energy $\left(\mathrm{MJ} \mathrm{ha}^{-1}\right)$ - Input energy $\left(\mathrm{MJ} \mathrm{ha}^{-1}\right)$

Output energy (MJ) / Total land (ha)

Output energy $\left(\mathrm{MJ} \mathrm{ha}^{-1}\right) /$ Non-renewable energy input $\left(\mathrm{MJ} \mathrm{ha}^{-1}\right)$

Labour+fuel+electricity $\left(\mathrm{MJ} \mathrm{ha}^{-1}\right)$

pesticides + insecticides + herbicides + machinery + manure + seed $\left(\mathrm{MJ} \mathrm{ha}^{-1}\right)$ Labour+FYM+seed $\left(\mathrm{MJ} \mathrm{ha}^{-1}\right)$

Machinery+diesel+electricity+chemical

fertilizers+pesticides+insecticides+herbicides $\left(\mathrm{MJ} \mathrm{ha}^{-1}\right)$
Chemical fertilizers +
Reference

Paramesh et al. (2018)

Mohammadi et al. (2010)

Paramesh et al. (2018)

Mohammadi et al. (2010)

Vanloon et al. (2005)

Vanloon et al. (2005)

Mohammadi et al. (2014)

Mohammadi et al. (2014)

Mohammadi et al. (2014)

Mohammadi et al. (2014)

Table 3 GHG emission coefficients of integrated crop-livestock system

Item

Machinery

Diesel

N

$\mathrm{P}$

$\mathrm{K}$

FYM

Electricity

Herbicide

Pesticide

Insecticide

Paddy

Milk

Mutton

Eggs

Poultry Unit

$\mathrm{kg} \mathrm{CO}_{2 \mathrm{eq}} \mathrm{MJ}^{-1}$

$\mathrm{kg} \mathrm{CO} 2 \mathrm{eq} \mathrm{L}^{-1}$

$\mathrm{kg} \mathrm{CO}_{2 \mathrm{eq}} \mathrm{kg}^{-1}$

$\mathrm{kg} \mathrm{CO}_{2 \mathrm{eq}} \mathrm{kg}^{-1}$

$\mathrm{kg} \mathrm{CO}_{2 \mathrm{eq}} \mathrm{kg}^{-1}$

$\mathrm{kg} \mathrm{CO}_{2 \mathrm{eq}} \mathrm{kg}^{-1}$

$\mathrm{kg} \mathrm{CO}_{2 \mathrm{eq}} \mathrm{kWh}^{-1}$

$\mathrm{kg} \mathrm{CO}_{2 \mathrm{eq}} \mathrm{kg}^{-1}$

$\mathrm{kg} \mathrm{CO}_{2 \mathrm{eq}} \mathrm{kg}^{-1}$

$\mathrm{kg} \mathrm{CO}_{2 \mathrm{eq}} \mathrm{kg}^{-1}$

$1.1 \mathrm{~kg} \mathrm{CH}_{4} /$ ha/day $\times 25 \mathrm{~kg} \mathrm{CO}_{2 \mathrm{eq}}$

$\mathrm{kg} \mathrm{CO}_{2 \mathrm{eq}} \mathrm{kg}^{-1}$

$\mathrm{kg} \mathrm{CO}_{2 \mathrm{eq}} \mathrm{kg}^{-1}$

$\mathrm{kg} \mathrm{CO}_{2 \mathrm{eq}} \mathrm{kg}^{-1}$

$\mathrm{kg} \mathrm{CO}_{2 \mathrm{eq}} \mathrm{kg}^{-1}$
GHG emission equivalent

0.071

2.76

1.3

0.2

0.15

0.126

0.8

3.9

5.1

6.3

1.1

3.4

23.8

4.2

6.6

\section{Referance}

Komleh et al., 2013

Moghimi et al., 2014

Lal, 2004

Lal, 2004

Lal, 2004

Komleh et al., 2013

Nguyen \& Hermansen., 2012

Soni et al., 2013

Soni et al., 2013

Lal, 2004

IPCC, 2006

Gerber et al., 2013

Gerber et al., 2013

Gerber et al., 2013

Gerber et al., 2013

Table 4 Rate of inputs applied in Crop production

\begin{tabular}{|c|c|c|c|c|c|c|c|c|}
\hline & Units & Rice & Maize & Sorghum & Tomato & Okra & Cotton & Groundnut \\
\hline Area & ha. & 37.74 & 14.04 & 0.25 & 0.90 & 0.30 & 1.0 & 0.20 \\
\hline \multicolumn{9}{|l|}{ Inputs } \\
\hline Human labour & $\mathrm{h}$ & 38696.0 & 12048.0 & 120.0 & 2160.0 & 1200.0 & 920.0 & 320.0 \\
\hline Bullock labour & $\mathrm{h}$ & 1622.4 & 760.0 & 0.0 & 128.0 & 8.0 & 160.0 & 24.0 \\
\hline Diesel & $\mathrm{L}$ & 3077.5 & 1035.0 & 2.5 & 12.5 & 20.0 & 40.0 & 5.0 \\
\hline Machinery & $\mathrm{h}$ & 615.5 & 207.0 & 0.5 & 2.5 & 4.0 & 8.0 & 1.0 \\
\hline Seed & $\mathrm{kg}$ & 2499.0 & 347.0 & 30.0 & 10.0 & 3.0 & 3.0 & 40.0 \\
\hline $\mathrm{N}$ & $\mathrm{kg}$ & 6667.5 & 2864.0 & 45.0 & 220.0 & 32.0 & 317.0 & 64.0 \\
\hline $\mathrm{P}$ & $\mathrm{kg}$ & 4053.0 & 1582.0 & 10.0 & 112.0 & 23.0 & 219.0 & 46.0 \\
\hline $\mathrm{K}$ & $\mathrm{kg}$ & 2683.0 & 790.0 & 0.0 & 12.0 & 0.0 & 45.0 & 0.0 \\
\hline FYM & $\mathrm{kg}$ & 165500.0 & 76000.0 & 1500.0 & 500.0 & 3000.0 & 10000.0 & 0.0 \\
\hline Electricity & $\mathrm{kWh}$ & 25000.0 & 1355.0 & 100.0 & 220.0 & 150.0 & 50.0 & 50.0 \\
\hline Herbicide & $\mathrm{kg}$ & 72.5 & 20.7 & 1.5 & 5.0 & 4.0 & 4.5 & 0.5 \\
\hline Pesticide & $\mathrm{kg}$ & 30.5 & 14.0 & 3.2 & 3.2 & 2.5 & 2.2 & 0.2 \\
\hline Insecticide & $\mathrm{kg}$ & 28.2 & 14.0 & 3.7 & 3.7 & 2.5 & 2.2 & 0.2 \\
\hline
\end{tabular}

Journal of Experimental Biology and Agricultural Sciences

http://www.jebas.org 


\begin{tabular}{|c|c|c|c|c|c|c|c|c|}
\hline & Units & Rice & Maize & Sorghum & Tomato & Okra & Cotton & Groundnut \\
\hline Area & ha & 37.74 & 14.04 & 0.25 & 0.90 & 0.30 & 1.00 & 0.20 \\
\hline \multicolumn{9}{|l|}{ Input energy } \\
\hline Human labour & $\mathrm{h}$ & 75844.7 & 23614.1 & 235.2 & 4233.6 & 2352.0 & 1803.2 & 627.2 \\
\hline Bullock labour & $\mathrm{h}$ & 16386.2 & 7676.0 & 0.0 & 1292.8 & 80.8 & 1616.0 & 242.4 \\
\hline Diesel & $\mathrm{L}$ & 173294.0 & 58280.8 & 140.8 & 703.9 & 1126.2 & 2252.4 & 281.5 \\
\hline Machinery & $\mathrm{h}$ & 38591.8 & 12978.9 & 31.3 & 94.0 & 250.8 & 501.6 & 62.7 \\
\hline Seed & $\mathrm{kg}$ & 36735.3 & 5100.9 & 441.0 & 9.6 & 4.4 & 54.0 & 949.2 \\
\hline $\mathrm{N}$ & $\mathrm{kg}$ & 404050.5 & 173558.4 & 2727.0 & 13332.0 & 1939.2 & 19210.2 & 3878.4 \\
\hline $\mathrm{P}$ & $\mathrm{kg}$ & 44988.3 & 17560.2 & 111.0 & 1243.2 & 255.3 & 2430.9 & 510.6 \\
\hline $\mathrm{K}$ & $\mathrm{kg}$ & 17976.1 & 5293.0 & 0.0 & 80.4 & 0.0 & 301.5 & 0.0 \\
\hline FYM & $\mathrm{kg}$ & 49650.0 & 22800.0 & 450.0 & 150.0 & 900.0 & 3000.0 & 0.0 \\
\hline Electricity & $\mathrm{kWh}$ & 300000.0 & 16260.0 & 1200.0 & 2640.0 & 1800.0 & 600.0 & 600.0 \\
\hline Herbicide & $\mathrm{kg}$ & 7400.1 & 2116.5 & 153.0 & 510.0 & 408.0 & 459.0 & 51.0 \\
\hline Pesticide & $\mathrm{kg}$ & 3660.0 & 1680.0 & 390.0 & 390.0 & 300.0 & 270.0 & 30.0 \\
\hline Insecticide & $\mathrm{kg}$ & 1638.5 & 812.0 & 217.5 & 217.5 & 145.0 & 130.5 & 14.5 \\
\hline Total & & 1170215.0 & 347730.8 & 6096.8 & 24959.7 & 9561.7 & 32629.3 & 7247.5 \\
\hline per ha. & & 31007.3 & 24767.1 & 24387.3 & 27733.0 & 31872.3 & 32629.3 & 36237.7 \\
\hline \multicolumn{9}{|l|}{ Output energy } \\
\hline Economic part & $\mathrm{kg}$ & 3275557.0 & 1483965.0 & & 4684.8 & 4088.0 & 30225.0 & 14238.0 \\
\hline Straw/fodder & $\mathrm{kg}$ & 2847325.0 & 1218125.0 & 59850.0 & 53950.0 & 19370.0 & 45500.0 & 7032.0 \\
\hline Total & & 6122882.0 & 2702090.0 & 59850.0 & 58634.8 & 23458.0 & 75725.0 & 21270.0 \\
\hline per ha. & & 162238.5 & 192456.6 & 239400.0 & 65149.8 & 78193.3 & 75725.0 & 106350.0 \\
\hline
\end{tabular}

Table 6 Input energy and output energy of livestock enterprise in integrated crop-livestock system

\begin{tabular}{|c|c|c|c|}
\hline & & & \\
\hline Buffalos & & & \\
\hline & Units & Quantity & Energy \\
\hline Dry fodder & $\mathrm{kg}$ & 289635.0 & 3620438.0 \\
\hline Concentrates & $\mathrm{kg}$ & 63879.0 & 748023.1 \\
\hline Human labour & $\mathrm{hr}$ & 54900.0 & 107604.0 \\
\hline Green fodder & $\mathrm{kg}$ & 102332.0 & 856314.2 \\
\hline Energy & & & 5332379.0 \\
\hline Sheep & & & \\
\hline Dry fodder & $\mathrm{kg}$ & 57890.0 & 723625.0 \\
\hline Concentrates & $\mathrm{kg}$ & 6205.0 & 72660.5 \\
\hline Human labour & $\mathrm{hr}$ & 8760.0 & 17169.6 \\
\hline Green fodder & $\mathrm{kg}$ & 1000.0 & 8368.0 \\
\hline Energy & & & 821823.2 \\
\hline Poultry & & & \\
\hline Concentrates & $\mathrm{kg}$ & 987.0 & 11557.7 \\
\hline Human labour & $\mathrm{hr}$ & 1302.0 & 2551.9 \\
\hline Energy & & & 14109.7 \\
\hline Total input energy of livestock & & & 6168311.9 \\
\hline Output & & & \\
\hline Milk & lit & 57632.0 & 282396.8 \\
\hline FYM & $\mathrm{kg}$ & 239800.0 & 71940.0 \\
\hline Mutton & $\mathrm{kg}$ & 10252.0 & 50644.9 \\
\hline Eggs & $\mathrm{kg}$ & 18.0 & 130.3 \\
\hline Poultry & $\mathrm{kg}$ & 148.0 & 3219.0 \\
\hline Total output energy of livestock & & & 408331.0 \\
\hline
\end{tabular}

Journal of Experimental Biology and Agricultural Sciences

http://www.jebas.org 
Table 7 Energy indices in crop production

\begin{tabular}{|lcccccccccc|} 
& Units & Rice & Maize & $\begin{array}{c}\text { Fodder } \\
\text { Sorghum }\end{array}$ & Tomato & Okra & Cotton & Groundnut & $\begin{array}{l}\text { Avg. of } \\
\text { crops }\end{array}$ \\
\hline EUE & & 5.23 & 7.77 & 9.82 & 2.35 & 2.45 & 2.32 & 2.93 & 4.70 \\
\hline Energy productivity & $\mathrm{kg} \mathrm{MJ}^{-1}$ & 0.19 & 0.29 & 0.74 & 0.20 & 0.29 & 0.06 & 0.08 & 0.26 \\
\hline Specific Energy & $\mathrm{MJ} \mathrm{kg}^{-1}$ & 5.25 & 3.44 & 1.35 & 5.11 & 3.41 & 16.73 & 12.08 & 6.77 \\
\hline Net Energy & $\mathrm{MJ} \mathrm{ha}^{-1}$ & 131231.2 & 167689.4 & 215012.7 & 37416.7 & 46321.1 & 43095.7 & 70112.2 & 101554.2 \\
\hline Land use efficiency & $\mathrm{MJ} \mathrm{ha}^{-1}$ & 162238.5 & 192456.5 & 239400.0 & 65149.8 & 78193.3 & 75725.0 & 106350.0 & 131359.0 \\
\hline $\begin{array}{l}\text { Non renewable energy } \\
\text { ratio }\end{array}$ & & 6.17 & 9.36 & 12.04 & 3.04 & 3.77 & 2.90 & 3.92 & 5.89 \\
\hline Direct energy & $\mathrm{MJ} \mathrm{ha}^{-1}$ & 14984.7 & 7537.8 & 6303.9 & 9855.8 & 17863.3 & 6271.6 & 8755.7 & $\begin{array}{l}10224.7 \\
(34.3 \%)\end{array}$ \\
\hline Indirect energy & $\mathrm{MJ} \mathrm{ha}^{-1}$ & 16022.5 & 17229.3 & 18083.4 & 17877.2 & 14008.9 & 26357.7 & 27482.0 & $\begin{array}{c}19580.2 \\
(65.7 \%)\end{array}$ \\
\hline Reneweable energy & $\mathrm{MJ} \mathrm{ha}^{-1}$ & 4732.8 & 4215.9 & 4504.8 & 6317.8 & 11123.9 & 6473.2 & 9094.0 & $\begin{array}{c}6637.5 \\
(22.3 \%)\end{array}$ \\
\hline Non renewable energy & $\mathrm{MJ} \mathrm{ha}^{-1}$ & 26274.5 & 20551.3 & 19882.5 & 21415.2 & 20748.3 & 26156.1 & 27143.7 & $\begin{array}{l}23167.4 \\
(77.7 \%)\end{array}$ \\
\hline
\end{tabular}

Table 8 Energy indices in livestock enterprise

\begin{tabular}{|c|c|c|c|c|}
\hline & & Energy productivity & Specific Energy & Net Energy \\
\hline Buffalos & 0.066 & 0.011 & 92.52 & -4978042.0 \\
\hline Goat & 0.061 & 0.012 & 80.16 & -771178.0 \\
\hline Poultry & 0.237 & 0.012 & 86.03 & -10760.4 \\
\hline
\end{tabular}

Input and output energies for the livestock enterprises are presented in table 6. Input energy required for the maintenance of dairy cattle, sheep, poultry were 5332379.0, 821823.2, 14109.7 MJ respectively. Total amount of energy input required was 6168311.9 MJ for livestock enterprise in the study area. The output energy was very low in livestock enterprise i.e. milk (282396.8 MJ), FYM (71940.0 MJ), mutton (50644.9 MJ), eggs (130.3 MJ) and poultry (3219.0 MJ). Total output energy for the livestock enterprise was 408331.0 MJ. The livestock enterprise has produced negative energy use of -5759980.9 MJ compared to consumed energy. The livestock enterprise was the most energy intensive component and was great consumer of the energy due to large use of feed ingredients and it is very labor intensive component compared with the crop enterprise.

Table 7 presents the energy indices for crops. The results of study revealed that energy use efficiency of overall crop enterprise was 4.70. It indicates that output energy 4.70 times to the input energy in crops in the study area. Helander \& Delin, (2004) reported that energy efficiency of integrated system is more than conventional system. With regards to individual crops, it was highest in fodder sorghum (9.82) and least in cotton (2.32). Lewandowski \& Schmidt (2006) stated that increase in chemical $\mathrm{N}$ fertilizer application decreases the energy efficiency. The energy productivity of the crops was calculated to be $0.26 \mathrm{~kg} \mathrm{MJ}^{-1}$, which means $0.26 \mathrm{~kg}$ output is produced per MJ energy consumption. In the present study energy productivity is highest for fodder sorghum $\left(0.74 \mathrm{~kg} \mathrm{MJ}^{-1}\right)$ and least for cotton $\left(0.06 \mathrm{~kg} \mathrm{MJ}^{-1}\right)$. Specific energy is the amount of energy in $\mathrm{MJ}$ required to produce the $1 \mathrm{~kg}$ economic yield. Crop enterprises have the mean specific energy of $6.77 \mathrm{MJ} \mathrm{kg}^{-1}$. It means $6.77 \mathrm{MJ}$ is required to produce $1 \mathrm{~kg}$ economic product. Fodder sorghum requires only $1.35 \mathrm{MJ}$ and cotton requires $16.73 \mathrm{MJ}$ to produce a $\mathrm{kg}$ of economic produce. Crop enterprise consumes $65.7 \%$ indirect energy and $77.7 \%$ of non renewable energy these findings are in line with Talukder et al. (2019). They reported that in rice production consumes substantial amount of non renewable energy i.e. $68-84 \%$ of total input energy. Crop enterprise have land use efficiency of $131359.0 \mathrm{MJ}$ $\mathrm{ha}^{-1}$, it means system produces $131359.0 \mathrm{MJ}$ output energy per ha area. Net gain of energy per ha area for crop enterprise was 101554.2 MJ. Deike et al. (2008) reported that high values of output energy results in greater net energy gain. Crop enterprise has the non renewable energy ratio of 5.89 .

Table 8 presents the various energy indices of livestock enterprises. The energy use efficiency of dairy cattle, sheep, poultry were 0.066 , $0.061,0.237$ respectively in the study area. Energy productivity of the livestock enterprises were dairy cattle (0.011), sheep (0.012) and poultry (0.012). Among the livestock enterprise, dairy cattle requires 92.52 MJ per liter of milk, sheep requires $80.16 \mathrm{MJ}$ to produce one 
$\mathrm{kg}$ of mutton and poultry requires $86.03 \mathrm{MJ}$ to produce one $\mathrm{kg}$ of poultry meat. All the three enterprises in the livestock have a negative energy gain. Pahlavan et al. (2011) stated that low energy efficiency in system is due to higher input energy.

Table 5 and 6 presents the results accounts for the energy performance of study area i.e. crop production and livestock respectively. Table 6 shows clearly that livestock enterprises consumes substantially higher energy and in return produces the very little output energy, which can potentially cause a serious impact on sustainability in long run. In this regard Moore (2010) stated that, increase the energy productivity of the system to attain the sustainability of production. It was quiet opposite in case of the crop enterprise, it consumes little energy and produces much higher output energy. As the farmers of the study area practices integrated livestock and crops, the total input energy for the study area (all 36 farmers) was $7766752.9 \mathrm{MJ}$ and output energy was 9472240.8 MJ. When the total system is considered, it is environmentally sustainable in long run, as system as positive energy of 1705487.9 MJ. This is made possible by the energy use saving in the crop enterprise; totally offset the livestock negative energy use. Livestock enterprise is a good revenue generation sector to farmers, it is recommended to go for integrated livestockcrops for the energy sustainability. Malcolm et al. (2015), also reported integration helps in lowering the energy use. According to Moraine et al. (2017) integration of crop-livestock farming systems promises a greater sustainability.

\subsection{Greenhouse gas emissions}

The data collected from the surveyed area, covering 36 farmers, where integrated livestock-crops were followed and converted into $\mathrm{kg} \mathrm{CO}$ 2eq by using the emission coefficients for crops and live stocks. GHG emissions regarding the crop production was presented in table 9. GHG emissions were highest in rice crop $\left(116969.6 \mathrm{~kg} \mathrm{CO}_{2 \mathrm{eq}}\right)$ it occupies an area of 37.74 ha of land, with mean of $3099.4 \mathrm{~kg} \mathrm{CO}_{2 \mathrm{eq}} \mathrm{ha}^{-1}$. Mohammadi et al. (2014) also reported that compared to all crops under study rice has produced highest GHG emissions. Maize occupies an area of 14.04 ha and had potential to emit GHG of $17929.9 \mathrm{~kg} \mathrm{CO}_{2 \text { eq }}$ with an average of $1277.1 \mathrm{~kg} \mathrm{CO}_{2 \mathrm{eq}} \mathrm{ha}^{-1}$, followed by cotton $\left(1916.8 \mathrm{~kg} \mathrm{CO}_{2 \mathrm{eq}}\right)$, okra (643.8 $\mathrm{kg} \mathrm{CO}_{2 \mathrm{eq}}$ ), tomato $\left(643.6 \mathrm{~kg} \mathrm{CO}_{2 \mathrm{eq}}\right)$, fodder sorghum (382.5 $\left.\mathrm{kg} \mathrm{CO} \mathrm{CO}_{2 \mathrm{q}}\right)$ and groundnut $\left(151.0 \mathrm{~kg} \mathrm{CO} \mathrm{Ce}_{2 \mathrm{q}}\right)$. Total $\mathrm{GHG}$ emissions from the crops were $138637.3 \mathrm{~kg} \mathrm{CO}$ eq in total of 54.43 ha. If we consider GHG emissions for specific area of ha it ranges between $715.4 \mathrm{~kg} \mathrm{CO}_{2 \mathrm{eq}} \mathrm{ha}^{-1}$ (tomato) to $3099.4 \mathrm{~kg} \mathrm{CO}_{2 \mathrm{eq}} \mathrm{ha}^{-1}$ (rice). Similar study was conducted by Tongwane et al. (2016) noticed that tomato crop management has produced $1650 \mathrm{~kg} \mathrm{CO}_{2 \mathrm{eq}} \mathrm{ha}^{-1}$. Bos et al. (2014) reported that GHG emission in crop production ranged from $45 \mathrm{~kg} \mathrm{CO}_{2 \mathrm{eq}} \mathrm{Mg}^{-1}$ (sugar beet) to $520 \mathrm{~kg} \mathrm{CO}_{2 \mathrm{eq}} \mathrm{Mg}^{-1}$ (pea).

Figure 1 presents the contribution of different parameters to GHG emissions for 1 ha crop production and figure was quite helpful to

Table 9 Amount of GHG emissions from crop and livestock enterprises

\begin{tabular}{|ccc|}
\hline & GHG $\left(\mathrm{kg} \mathrm{CO}{ }_{2}\right.$ eq $)$ in surveyed area & GHG $\left(\mathrm{kg} \mathrm{CO}_{2} \mathrm{eq}\right) / \mathrm{ha}$ \\
\hline Crops & & 3099.4 \\
\hline Rice & 116969.6 & 1277.1 \\
\hline Maize & 17929.9 & 1529.9 \\
\hline Todder sorghum & 382.5 & 715.1 \\
\hline Okra & 643.6 & 2145.9 \\
\hline Cotton & 643.8 & 1916.8 \\
\hline Groundnut & 1916.8 & 755.4 \\
\hline Crops total & 151.1 & \\
\hline & 138637.3 & \\
\hline Milk & & \\
\hline FYM & 195948.8 & \\
\hline Mutton & 30214.8 & \\
\hline Eggs & 166362.0 & \\
\hline Poultry & 75.6 & \\
\hline Livestock total & 976.8 & \\
\hline Overall total & 393578.0 & \\
\hline
\end{tabular}

Journal of Experimental Biology and Agricultural Sciences http://www.jebas.org 


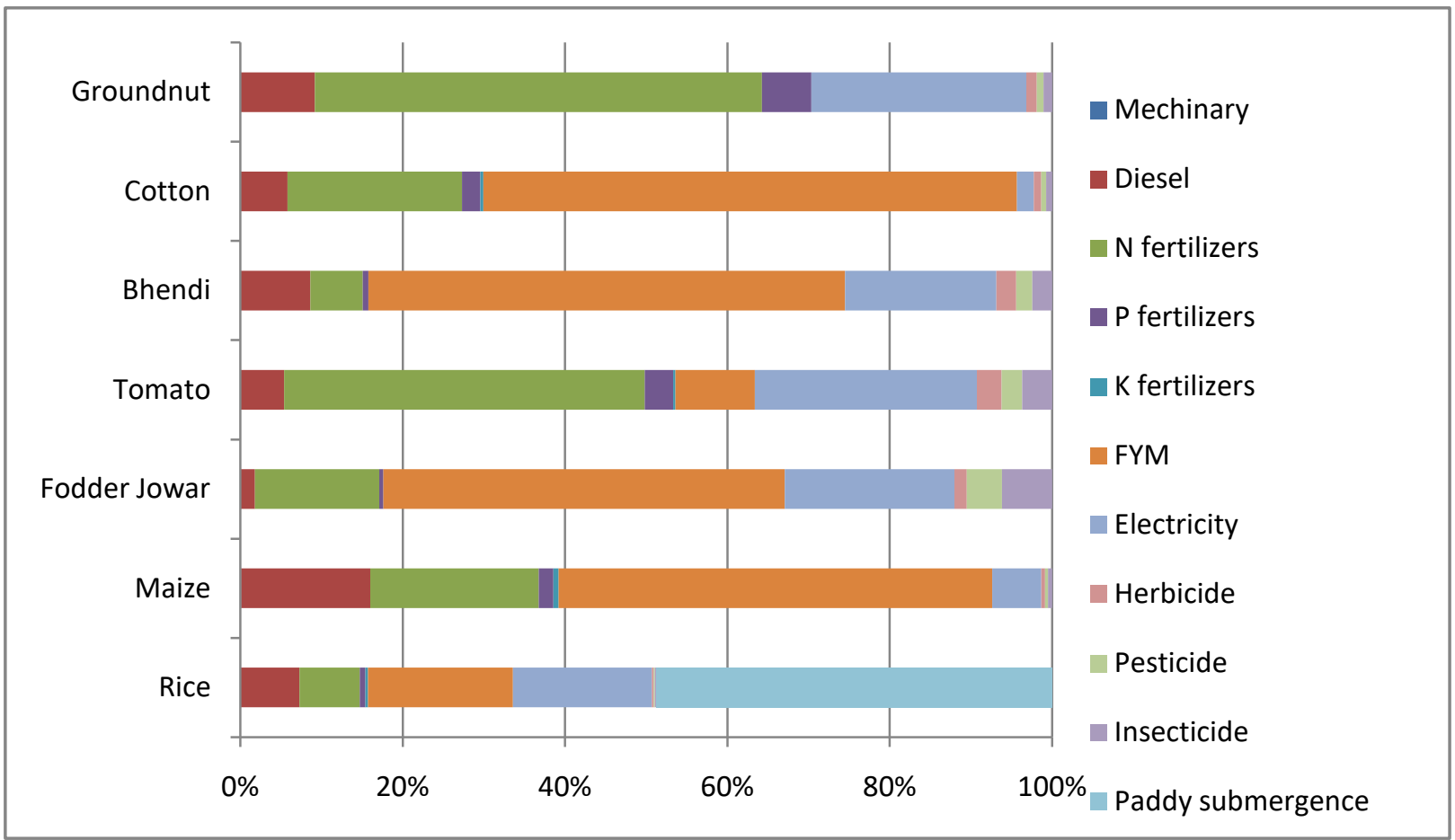

Figure 1 Contribution of different parameters in the GHG emissions of 1 ha crop production in study area

assess the role of different parameters for GHG emissions in crop production. For rice production, submergence of crop was the most important source for GHG emissions followed by electricity and FYM application. Similar findings were summarized by Liu et al. (2010); Nayak et al. (2015) and Xu et al. (2017). Rice crop under submergence (continuous flooding) generates $\mathrm{CH}_{4}$ emissions because of reduced conditions in soil. While in cotton, okra, fodder sorghum, maize, the application of FYM was among the most important contributor of GHG emission. In the study, after FYM, electricity and $\mathrm{N}$ fertilizers play a pivotal role in GHG emissions. Sarauskis et al. (2019) also reported that FYM fertilization resulted in increase in GHG emissions.

As the input energy was very high to produce a specific quantity of livestock products and was expected that GHG emissions from the livestock will be higher than the crop production. The results of the GHG emission was summarized in the table 9 (in lower panal). In the study 177 dairy cattle and bullocks has produced 57637 lit of milk, $6740 \mathrm{~kg}$ of meat, $239800 \mathrm{~kg}$ of FYM. The $\mathrm{CO}_{2}$ emission coefficient to produce a liter of milk, $\mathrm{kg}$ of meat and FYM were $3.4,36.8$ and $0.126 \mathrm{~kg} \mathrm{CO}_{2 \text { eq }}$ respectively. The dairy cattle produces $195948.8,30214.8 \mathrm{~kg} \mathrm{CO} \mathrm{CO}_{2 \mathrm{eq}}$ for production of milk, FYM respectively. In total produces $226163.6 \mathrm{~kg} \mathrm{CO} \mathrm{CO}_{2 \mathrm{eq}}$ from the dairy cattle components. Similar findings were reported by Mariantonietla et al. (2017) in Italy, these researchers stated that production of milk was one of the important factors for GHG emissions in agriculture. GHG emissions associated with sheep were presented in table 9. To produce a $\mathrm{kg}$ of mutton the $\mathrm{CO}_{2}$ emission coefficient was $23.8 \mathrm{~kg} \mathrm{CO}_{2 \mathrm{eq}}$. In the study year sheep weight was $10252 \mathrm{~kg}$. The potential GHG emission from sheep components was $166362.0 \mathrm{~kg} \mathrm{CO}_{2 \text { eq. }}$ The $\mathrm{CO}_{2}$ emission coefficient for eggs and poultry meat was 4.2 and $6.6 \mathrm{~kg} \mathrm{CO}_{2 \mathrm{eq}}$ $\mathrm{kg}^{-1}$. The production of eggs and poultry meat in study was 18.0 $\mathrm{kg}$ and $148.0 \mathrm{~kg}$ respectively. So, the poultry component can produce the GHG emissions of $1052.4 \mathrm{~kg} \mathrm{CO}_{2 \text { eq }}$. Total GHG emissions from the livestock enterprises were $641610.0 \mathrm{~kg}$ $\mathrm{CO}_{2 \mathrm{eq}}$. Whole study area GHG emission was $780247.3 \mathrm{~kg} \mathrm{CO}_{2 \mathrm{eq}}$. Vetter et al. (2017) reported that GHG emission was highest for rice and livestock products. The plant protein to animal protein conversion was inefficient in livestock, this was the utmost important point for the high GHG emissions from livestock as reported by Ripple et al. (2014). Li et al. (2017) concluded that integrated livestock-crop systems can reduce the net GHG emissions by $10.15 \%$ compared to two separate systems. Saltona et al. (2014) and Buller et al. (2015) conducted a case study in Pantanal savanna highland, Brazil regarding integrated croplivestock systems and summarized that system can improve soil fertility and mitigate GHG emissions helps towards a more sustainable agriculture in long term for Brazilian cerrado. 


\section{Conclusion}

The principal aim of the current study was to assess the energy use and GHG emissions from integrated crop-livestock systems in semi arid Deccan plateau of Southern India and their sustainability in long run. Policy makers are very keen at popularizing the integrated crop-livestock system, assessing energy dynamics and environmental impact of the system helps in its sustainability in future. The information regarding inputs and outputs were collected from 36 farmers, integrated crop-livestock was evaluated in terms of energy use and GHG emissions. Among enterprises, crop enterprise in the system was highly efficient in energy while livestock enterprise was very highly inefficient. The results indicate that crop enterprise consumed 1598441.0 MJ of energy and generated $9063909.8 \mathrm{MJ}$. Crop enterprise has a positive energy balance of 7465468.8 MJ. Energy use efficiency of 4.7 and it consumed indirect $(65.7 \%)$, non renewable energy $(77.7 \%)$ greater than direct $(34.3 \%)$ and renewable energy (22.3\%). Regards to livestock enterprise, it consumed 6168311.9 MJ of energy and produced 408331.0 MJ. This enterprise has a negative energy balance of -5759980.9 MJ. Overall, the net energy balance of integrated crop-livestock system was 1705487.9. It implies, negative energy balance in livestock enterprise is neutralized by positive energy balance of the crop enterprises. On a whole integrated crop-livestock system can sustain in long run due to positive energy balance the system. Livestock enterprise alone sustainability is big issue in future.

Comparison between energy input and emitted $\mathrm{CO}_{2}$ in the study area showed that there was a direct relationship between energy input and $\mathrm{CO}_{2}$ emissions. In $\mathrm{GHG}$ emission analysis in crop enterprise emissions ranged between $3099.4 \mathrm{~kg} \mathrm{CO}_{2 \mathrm{eq}} \mathrm{ha}^{-1}$ (rice) to $715.4 \mathrm{~kg} \mathrm{CO}_{2 \mathrm{eq}} \mathrm{ha}^{-1}$ (tomato). Among the crops rice has emitted greater $\mathrm{kg} \mathrm{CO}_{2 \mathrm{eq}} \mathrm{ha}^{-1}$ per specific area and $50 \%$ of emissions were caused by submergence of rice crop. Total GHG emissions form crop enterprise was $138637.3 \mathrm{~kg} \mathrm{CO}_{2 \text { eq. }}$ Livestock enterprise production system emitted $641610.0 \mathrm{~kg}$ $\mathrm{CO}_{2 \mathrm{eq}}$, it was much higher compared to crop enterprises in study area. To whole system has produced $780247.3 \mathrm{~kg} \mathrm{CO}_{2 \text { eq. }}$ Livestock production represents the one of the prime source of income for small and marginal farmers and was the protein supplement in this part of India. This study clearly insight that integrating livestock with crop production is best possible option to increase the energy use and to reduce GHG emissions that helps in environmental sustainability. Hope, all the farmers will convert to integrated crop-livestock and policy makers should encourage the system, so that farming will be sustained both in energy use and environmental impact.

\section{Conflict of interest}

Not have any conflict of interest with any one of co authors and others.

\section{References}

Akcaoz H, Ozcatalbas O, Kizilay H (2009) Analysis of energy use for pomegranate production in Turkey. Journal of Food, Agriculture and Environment 7: 475-80.

Barber A (2004) Seven Case Study Farms: Total Energy \& Carbon Indicators for New Zealand Arable \& Outdoor Vegetable Production. AgriLINK New Zealand Ltd, Pukekohe. Available on http://www.agrilink.co.nz/Files/Arable_Vegetable_Energy_Use_M ain_Report.pdf access on 21 October, 2019.

Bos JFFP, Haan JD, Sukkel W, Schils RLM (2014) Energy use and greenhouse gas emissions in organic and conventional farming systems in the Netherlands. NJAS-Wageningen Journal of Life $\begin{array}{lll}\text { Sciences } & 68 \text { : } & 61-70 .\end{array}$ http://dx.doi.org/10.1016/j.njas.2013.12.003.

Buller LS, Bergier I, Ortega E, Moraes A, Bayma-Silva G, Zanetti MR (2015) Soil improvement and mitigation of greenhouse gas emissions for integrated crop-livestock systems: Case study assessment in the Pantanal savanna highland, Brazil. Agricultural Systems 137: 206-219. DOI: http://dx.doi.org/10.1016/j.agsy.2014.11.004.

Cao MH, Adeola O (2015) Energy value of poultry by product meal and animal-vegetable oil blend for broiler chickens by the regression method. Poultry Science 95: 268-275. DOI: http://dx.doi.org/10.3382/ps/pev317.

Chandrakar SK, Soni DL, Yadav DK, Sahu LK (2013) Experimental study on animal powered mechanical device for home lighting system. International Journal of Environmental Engineering and Management 4: 471-482.

Chaudhary VP, Gangwar B, Pandey DK, Gangwar KS (2009) Energy auditing of diversified rice- wheat cropping systems in Indo-gangetic plains. Energy 34: 1091-1096. DOI: https://doi.org/10.1016/j.energy.2009.04.017.

Deike S, Pallutt B, Christen O (2008) Investigations on the energy efficiency of organic and integrated farming with specific emphasis on pesticide use intensity. European Journal of Agronomy 28: 461-470. doi:10.1016/j.eja.2007.11.009

Devasenapathy P, Senthilkumar G, Shanmugam PM (2009) Energy management in crop production. Indian Journal of Agronomy 54: 80-89. 
Gerber PJ, Steinfeld H, Henderson B, Mottet A, Opio C, Dijkman J, Falcucci A, Tempio G (2013) Tackling climate change through livestock-A global assessment of emissions and mitigation opportunities. Food and Agriculture Organization of the United Nations (FAO), Rome.

Ghahramani A, Bowran D (2018) Transformative and systemic climate change adaptations in mixed crop livestock farming systems. Agricultural Systems 164: 236-251. DOI https://doi.org/10.1016/j.agsy.2018.04.011.

Gopalan C, Sastri BVR, Balasubramanian SC (2012) Nutritive value of Indian foods. National institute of nutrition, ICMR, Hyderabad.

Helander CA, Delin K (2004) Evaluation of farming systems according to valuation indices developed within a European network on integrated and ecological arable farming systems. European Journal of Agronomy 21: 53-67. doi:10.1016/S11610301(03)00089-3.

Hoffman E, Cavigelli MA, Camargo G, Ryan M, Ackroyd VJ, Richard TL, Mirsky S (2018) Energy use and greenhouse gas emissions in organic and conventional grain crop production: Accounting for nutrient inflows. Agricultural systems 162: 89-96 https://doi.org/10.1016/j.agsy.2018.01.021.

ICAR (2015) VISION 2020-Indian Council of Agricultura Research. ICAR, New Delhi, India.

INCCA (2010) India : Greenhouse Gas Emissions 2007. Indian Network for Climate Change Assessment, Ministry of Environment and Forests, Government of India.

IPCC (2006) Guidelines for national greenhouse gas inventories. In: Eggleston HS, Buendia L, Miwa K, Ngara T, Tanabe K (Eds), Prepared by the national greenhouse gas inventories programme. 2006. Japan: IGES available on http://www.ipccnggip.iges.or.jp/public/2006gl/index.htm access on 20 October,2019.

Intergovernmental Panel on Climate Change - IPCC (2007) Climate Change 2007: Impacts, Adaptation and Vulnerability. Summary for policy makers. Available on http://www.ipcc.cg/SPM13apr07.pdf access on 20 October,2019.

Komleh SHP, Omid M, Heidari MD (2013) On the study of energy use and GHG (greenhouse gas) emissions in greenhouse cucumber production in Yazd province. Energy 59: 63-71. DOI: https://doi.org/10.1016/j.energy.2013.07.037

Koopmans A, Koppejan J (1997) Agricultural and forest residuesgeneration, utilization and availability. In: Regional consultation on modern applications of biomassenergy 1997 held at, Kualampur, Malaysia: FAO on 6-10January1997.

Krishnamoorthy U, Solled H, Steingass H, Menke KH (1995) Energy and protein evaluation of tropical feed stuffs for whole tract and ruminal digestion by chemical analyses and rumen inoculum studies in vitro. Animal Feed Science and Technology 52: $177-188$.

Lal R (2004) Carbon emission from farm operations. Environment International $\quad 30: \quad 981-990 . \quad$ DOI: https://doi.org/10.1016/j.envint.2004.03.005.

Larson DL, Fangmeir DD (1978) Energy in irrigated crop production. Transactions of the American Society of Agricultural Engineers 21:1075-1080.

Lewandowski I, Schmidt U (2006) Nitrogen, energy and land use efficiency of miscanthus, reed canary grass and triticale as determined by the boundary line approach. Agriculture, Ecosystem \& Environment 112: 335-346.

Li Z, Sui P, Wang X, Yang X, Long P, Cui J, Yan L, Chen Y (2017) Comparison of net GHG emissions between separated system and crop-swine integrated system in the North China Plain. Journal of Cleaner Production 149: 653-664. DOI: http://dx.doi.org/10.1016/j.jclepro.2017.02.113.

Liu S, Qin Y, Zou J, Liu Q (2010) Effects of water regime during rice-growing season on annual direct $\mathrm{N}_{2} \mathrm{O}$ emission in a paddy rice-winter wheat rotation system in southeast China. Science of the Total Environment 408: 906-913.

Malcolm GM, Camargo GGT, Ishler VA, Richard TL, Karsten HD (2015) Energy and greenhouse gas analysis of northeast US dairy cropping systems. Agricultural, Ecosystem \& Environment 199: 407-417.

Mariantonietta F, Alessia S, Francesco C, Giustina P (2017) GHG and Cattle Farming: Co-Assessing the Emissions and Economic Performances in Italy. Journal of Cleaner Production 172: 37043712. doi: 10.1016/j.jclepro.2017.07.167.

Mobtaker HG, Akram A, Keyhani A, Mohammadi A (2012) Optimization of energy required for alfalfa production using data envelopment analysis approach. Energy Sustainable Development 16: 242-248. DOI: https://doi.org/10.1016/j.esd.2012.02.001.

Moghimi MR, Pooya M, Mohammadi A (2014) Study on energy balance, energy forms and greenhouse gas emission for wheat production in Gorve city, Kordestan province of Iran. European Journal of Experimental Biology 4: 234-239. 
Mohammadi A, Rafiee S, Jafari A, Keyhani A, Avval SHM, Nonhebel S (2014) Energy use efficiency and greenhouse gas emissions of farming systems in North Iran. Renewable and Sustainable Energy Reviews 30: 724-733.

Mohammadi A, Rafiee S, Mohtasebi SS, Rafiee H (2010) Energy inputs-yield relationship and cost analysis of kiwifruit production in Iran. Renewable Energy 35: 1071-1075.

Mondal AH (2010) Implications of renewable energy technologies in the Bangladesh power sector: long-term planning strategies. ZEF. Ph D Thesis. ISBN: 978-3-940124-25-8

Moore SR (2010) Energy efficiency in small-scale bio intensive organic onion production in Pennsylvania, USA. Renewable Agriculture and Food System 25: 181-188.

Moraine M, Melaca P, Ryschawya J, Durua M, Theronda O (2017) A participatory method for the design and integrated assessment of crop-livestock systems in farmer's groups. Ecological Indicators 72: $340-351$.

Nayak D, Saetnan E, Cheng K, Wang W, Koslowski F, Cheng Y, Zhu WY, Wang J, Liu J, Moran D, Yan X, Cardenas L, Newbold J, Pan G, Lu Y, Smith P (2015) Management opportunities to mitigate greenhouse gas emissions from Chinese agriculture. Agricultural Ecosystems and Environment 209: 108-124.

Nguyen TLT, Hermansen JE (2012) System expansion for handling co-products in LCA of sugarcane bio-energy systems: GHG consequences of using molasses for ethanol production. Applied Energy 89: 254-261.

Ozkan B, Akcaoz H, Fert C (2004) Energy input-output analysis in Turkish agriculture. Renewable Energy 29: 39-51.

Ozturk HH, Bascetincelik A (2006) Energy exploitation of agricultural biomass potential in Turkey. Energy Exploration \& Explotation 24: 313-330.

Pahlavan R, Omid M, Akram A (2011) Energy use efficiency in greenhouse tomato production in Iran. Energy 36: 6714-6719. DOI: https://doi.org/10.1016/j.energy.2011. 10.038.

Paramesh V, Arunachalam V, Nikkhah A, Das B, Ghnimi S (2018) Optimization of energy consumption and environmental impacts of arecanut production through coupled data envelopment analysis and life cycle assessment. Journal of Cleaner Production 203: 1-11. DOI: https://doi.org/10.1016/j.jclepro.2018.08.263.

Petal A (2012) Nutritive value of commonly available feeds and fodders in India. Animal nutrition group, National Dairy Development Board, Anand.
Rafiee S, Avval SHM, Mohammadi A (2010) Modelling and sensitivity analysis of energy inputs for apple production in Iran. Energy 35: 3301-3306. DOI: https://doi.org/10.1016/j.energy.2010.04.015.

Rahman S, Barmon BK (2012) Energy productivity and efficiency of the 'gher' (prawn-fish-rice) farming system in Bangladesh. Energy 43: 293-300. DOI: https://doi:10.1016/j.energy.2012.04.027.

Ripple WJ, Smith P, Haberl H, Montzka SA, McAlpine C, Boucher DH (2014) Ruminants, climate change and climate policy. Nature Climate Change 4: 2-5.

Rosegrant MW, Cai X, Cline SA (2002) Global water outlook to 2025: Averting and impending crisis. International Water Management Institute (IWMI), 2020 Vision for Food, Agriculture, and the Environment, International Food Policy Research Institute (IFPRI). Washington, D.C, Colombo, Sri Lanka.

Saltona JC, Mercantea FM, Tomazi M, Zanatta JA, Concenc G, Silva WM, Retorea M (2014) Integrated crop-livestock system in tropical Brazil: Toward a sustainable production system. Agriculture, Ecosystems and Environment 190: 70-79. DOI: http://dx.doi.org/10.1016/j.agee.2013.09.023.

Sarauskis E, Masilionyte L, Juknevicius D, Buragiene S, Kriauciuniene Z (2019) Energy use efficiency, GHG emissions and cost-effectiveness of organic and sustainable fertilization. Energy 172: $1151-1160$.

Sartori L, Basso B, Bertocco M, Oliviero G (2005). Energy Use and Economic Evaluation of a Three Year Crop Rotation for Conservation and Organic Farming in NE Italy. Biosystems Engineering 91: 245-256.

Sefeedpari P, Rafiee S, Komleh SHP, Ghahderijani M (2012) A source-wise andoperation-wise energy use analysis for corn silage production, a case study of Tehranprovince, Iran. International Journal of Sustainable Built Environment 1: 158-166.

Soni P, Taewichit C, Salokhe VM (2013) Energy consumption and $\mathrm{CO} 2$ emissions in rainfed agricultural production systems of Northeast Thailand. Agricultural systems 116: 25-36.

Steinfeld H, Gerber P, Wassenaar T, Castel V, Rosales M, Haan CD (2006) Livestock's Long Shadow: Environmental Issues and Options. Food and Agriculture Organization of the United Nations (FAO).

Tabar BI, Keyhani A, Rafiee S (2010) Energy balance in Iran's agronomy (1990-2006). Renewable Sustainable Energy Reviews 14: $849-855$. 
Talukdera B, Vanloonb GW, Hipel KW (2019) Energy efficiency of agricultural systems in the southwest coastal zone of Bangladesh. Ecological Indicators 98: 641-648. DOI: https://doi.org/10.1016/j.ecolind.2018.11.030.

Tongwane M, Mdlambuzi T, Moeletsi M, Tsubo M, Mliswa V, Grootboom L (2016) Greenhouse gas emissions from different crop production and management practices in South Africa. Environmental Development 19: 23-35. http://dx.doi.org/10.1016/j.envdev.2016.06.004.

Tsatsarellis CA (1991) Energy requirements for cotton production in Central Greece. Journal of Agricultural Engineering Research. 50: 239-246.
Vanloon GW, Patil SG, Hugar LB (2005) Agricultural Sustainability: Strategies for Assessment. SAGE.

Vetter SH, Sapkota TB, Hillier J, Stirling CM, Macdiarmid JI, Aleksandrowicz ., Green R, Joy EJM, Dangour AD, Smith P (2017) Greenhouse gas emissions from agricultural food production to supply Indian diets: Implications for climate change mitigation. Agriculture, ecosystems and environment. 237: 234241. DOI: http://dx.doi.org/10.1016/j.agee.2016.12.024.

Xu G, Liu X, Wang Q, Yu X, Hang Y (2017) Integrated rice-duck farming mitigates the global warming potential in rice season. Science of the Total Environment 575: 58-66. DOI: http://dx.doi.org/10.1016/j.scitotenv.2016.09.233. 